\author{
R.S. Kozhanova ${ }^{1,4^{*}}$, B.K. Rakhadilov ${ }^{2}$, W. Wieleba ${ }^{3}$ \\ ${ }^{I}$ PlasmaScience LLP, Ust-Kamenogorsk, Kazakhstan; \\ ${ }^{2}$ Sarsen Amanzholov East Kazakhstan University, Ust-Kamenogorsk, Kazakhstan; \\ ${ }^{3}$ Wroclaw University of Science and Technology, Wroclaw, Poland; \\ ${ }^{4}$ Shakarim University, Semey, Kazakhstan \\ ('e-mail:kozhanovars@yandex.kz)
}

\title{
Interaction model of low-temperature plasma with a steel surface during electrolyte plasma nitriding in an electrolyte on the bases of carbamide
}

\begin{abstract}
The features of the formation of low-temperature plasma and its interaction with a metal surface were studied in this work. A qualitative model of the interaction of low-temperature plasma with the steel surface during nitriding has been developed by summarizing the available research results and taking into account the specific features of the electrolyte plasma process. In accordance with this model, in the first moments of the interaction of low-temperature plasma with the steel surface in the near-surface layer, which accelerated formation of the $\mathrm{Fe}_{\alpha(\mathrm{N})}$ solid solution occurs due to the action of directed bombardment of charged particles, which enhances the adsorption and diffusion of nitrogen into the interior of the material, then dispersed particles of nitride of alloying elements are formed as further saturation in places with an increased level of free energy (at lattice defects, at grain boundaries, etc.). Subsequently, transformations occur in the surface zone of the layer when the limiting solubility of nitrogen in iron is exceeded, which leading to the formation of nitrides of the $\gamma^{\prime}$-phase $\left(\mathrm{Fe}_{4} \mathrm{~N}\right)$ and $\varepsilon$-phase $\left(\mathrm{Fe}_{2-3} \mathrm{~N}\right)$ in it. Thus, electrolyte plasma nitriding opens up many new possibilities, in particular: varying the nitriding temperature over a wide range $\left(400-700^{\circ} \mathrm{C}\right)$, targeted production of a nitrided layer consisting only of a diffusion layer without a layer of compounds, while obtaining a diffusion layer with particles $\gamma$ '-phase $\left(\mathrm{Fe}_{4} \mathrm{~N}\right)$ of plate form and with finely dispersed nitrides $\mathrm{MN}(\mathrm{CrN})$. The use of an electric discharge in an electrolyte (low-temperature plasma) makes it possible to increase the heating rate and diffusion saturation of the material surface. This work is of practical importance, since the studied method of electrolytic-plasma nitriding makes it possible to obtain a modified surface layer on steels with high physical and mechanical properties.
\end{abstract}

Keywords: plasma, electrolyte-plasma treatment, nitriding, saturation, electrolyte, steel, model, modified layer, phase.

\section{Introduction}

Plasma electrolyte treatment is based on the interaction of ions, electrons, excited atoms and other energetic particles obtained in low-temperature plasma with the surface of a solid [1,2]. An electrolyte is used to create and maintain a low-temperature plasma in nitriding, which is a source of ions for carrying out the nitriding process: an aqueous solution of salts containing nitrogen ions, an aqueous solution of ammonia and other nitrogen-containing media. On the basis of experimental studies, it was found that the most effective and promising electrolyte for electrolyte-plasma nitriding of steels is an electrolyte from an aqueous solution containing $20 \%$ carbamide and $10 \%$ sodium carbonate [3]. In the developed electrolyte, the nitrogencontaining component is carbamide, and the component that ensures the electrical conductivity of the electrolyte is sodium carbonate [3-5]. Water is used as a solvent. The main advantage of this electrolyte is its exceptional low cost, since the initial components are produced in mass quantities and are widely used in the national economy. They also do not belong to highly toxic substances that require special safety measures.

The results obtained in work [3-5] showed that plasma electrolyte nitriding in an electrolyte from an aqueous solution containing $20 \%$ carbamide and $10 \%$ sodium carbonate makes it possible to obtain a modified surface layer consisting of nitrogenous martensite, carbides $\mathrm{M}_{6} \mathrm{C}, \mathrm{MC}$ and $\mathrm{Fe}_{4} \mathrm{~N}$ nitrides, $\mathrm{CrN}$.

As is known [6, 7], nitriding by electrolyte-plasma heating not only shortens the time required to reach the required temperature of the part, but also accelerate the formation of diffusion layers. The reason for this is the positive effect of heating conditions and a saturating environment on some elementary nitriding processes.

It is necessary to study the features of the formation of low-temperature plasma and its interaction with a metal surface in order to gain a deeper understanding of the physical processes that determine the formation of the composition, structure and properties of the nitrided layer, during electrolyte-plasma nitriding. 


\section{Results and discussions}

As it is known [8,9], the interaction of the saturating medium with the surface of the metal being treated during CTT is usually divided into the following stages:

1. Formation of active substances in the environment or reaction volume.

2. Supply of a saturating substance to the metal surface.

3. Adsorption of active atoms or molecules by the metal surface.

4. Chemical reactions on the surface (layer growth due to chemical reaction or diffusion), as well as the formation of reaction products in an adsorbed state.

5. Desorption of reaction products.

6. Removal of reaction products from the interaction zone into the reaction volume or environment.

Based on this, we will consider the main stages of interaction of the saturating medium with the treated surface during the electrolyte-plasma treatment of steel in an electrolyte from an aqueous solution containing $20 \%$ carbamide and $10 \%$ sodium carbonate.

The workpiece is immersed in an open reactor (electrolytic cell) filled with electrolyte during the nitriding process. A rectified voltage is applied to the part (cathode) and solid electrode (anode). A gas-steam jacket with a thickness of about 100-120 $\mu \mathrm{m}$ is created near the surface of the part (Fig. 1) [10]. The gasvapor shell enveloping the workpiece contains electrolyte ions and, accordingly, nitrogen ions. It is a lowtemperature plasma and is an active saturating atmosphere for nitriding. This saturating medium is dense the pressure in the reactor corresponds to atmospheric [11].

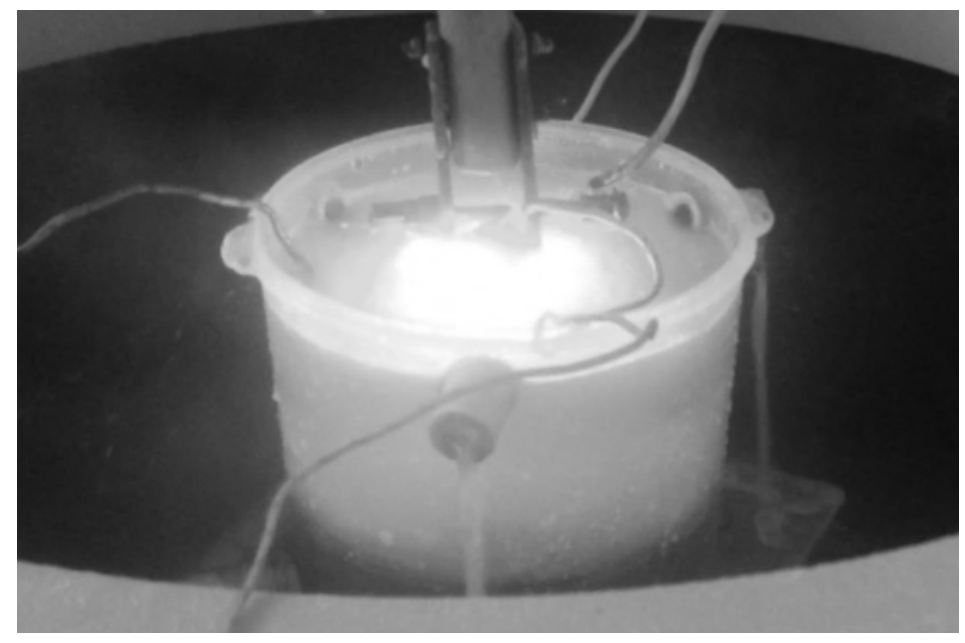

Figure 1. The process of electrolyte plasma nitriding of a steel sample

Thus, plasma electrolyte nitriding consists in processing products in a low-temperature plasma (vaporgas shell) created between the electrolyte and the surface of the products.

Let us consider the features of the formation of active substances in a vapor-gas shell during nitriding of steels in an electrolyte from an aqueous solution containing $20 \%$ carbamide and $10 \%$ sodium carbonate.

Near the vapor-gas shell, the components of the aqueous solution enter into a reaction, with the release of a large amount of gases - ammonia, carbon dioxide and water vapor, which enters the vapor-gas shell:

$$
2\left(\mathrm{NH}_{2}\right)_{2} \mathrm{CO}+\mathrm{Na}_{2} \mathrm{CO}_{3} \rightarrow 2 \mathrm{NaNCO}+2 \mathrm{NH}_{3}{ }^{\uparrow}+\mathrm{CO}_{2}{ }^{\uparrow}+\mathrm{H}_{2} \mathrm{O}
$$

Sodium cyanate synthesized by fusion of carbamide with sodium carbonates is moderately soluble in water. In water and in water vapor, sodium cyanate hydrolyzes to $\mathrm{Na}_{2} \mathrm{CO}_{3}, \mathrm{CO}_{2}$ и $\mathrm{NH}_{3}$ :

$$
2 \mathrm{NaNCO}+3 \mathrm{H}_{2} \mathrm{O} \rightarrow \mathrm{Na}_{2} \mathrm{CO}_{3}+\mathrm{CO}_{2}^{\uparrow}+2 \mathrm{NH}_{3}{ }^{\uparrow}
$$

Hydrolysis intensifies at the boundary between the electrolyte and the vapor-gas shell, since the temperature in it is high.

In the course of the reaction at the boundary between the electrolyte and the vapor-gas shell, the released ammonia, entering the vapor-gas shell, decomposes with the release of atomic nitrogen:

$$
2 \mathrm{NH}_{3} \rightarrow 3 \mathrm{H}_{2}+2 \mathrm{~N} \bullet
$$


As a result, nitrogen is formed in the vapor-gas envelope, which is in an atomic state, and in this form is very chemically active.

It is necessary to maintain the composition of the vapor-gas shell in order to ensure stable formation of active ions of atomic nitrogen and saturation. This requires a constant supply of a saturating substance (electrolyte) to the vapor-gas shell (low-temperature plasma), thereby preserving the composition of the vapor-gas shell. It also provides a stable discharge in the vapor-gas envelope. Thus, the supply of the active medium to the metal surface and the removal of reaction products from the interaction zone are provided by the circulation of the electrolyte. The surface concentration of the element, which determines the thickness of the diffusion layer, depends on the ratio of the rates of delivery of active atoms to the surface and their diffusion into the metal. It is necessary that the rate of its adsorption exceeds the rate of diffusion to achieve a high concentration of the saturating component on the metal surface [12].

The initial stage of the diffusion process is the bombardment of the metal surface of the cathode with charged particles $\left(\mathrm{H}^{+}, \mathrm{N}^{+}, \mathrm{Na}^{+}\right)$, which leads to cleaning and heating of the surface at a distance of more than $100 \mu \mathrm{m}$, as well as to the initiation of vacancies and other defects in the crystal lattice, due to which the diffusion fraction increases through the crystal lattice of the metal. Avalanches of electrons arising during the development of a discharge in the electrolyte and forming well-conducting streamer channels, along which a current pulse runs at a high speed of $\sim 10^{7}-10^{8} \mathrm{~m} / \mathrm{s}$ and a backward voltage wave propagates, make a large contribution to the heating of the metal. When the reverse voltage wave passes in the next period of time, with a duration of about $10^{-7} \mathrm{~s}$, a large amount of energy is released in the channel. As a result, an abrupt increase in pressure occurs, and a cylindrical shock wave propagates into the space surrounding the channel, the temperature at the front of which is about $10^{4} \mathrm{~K}$. In this case, the ionization of the particles of the vaporgas medium, the formation of additional branches of the channels with the involvement of charged ions in the avalanche [13].

Atomic nitrogen released in the vapor-gas envelope during chemical reactions is adsorbed by iron and diffuses deep into the material to form a solid solution of nitrogen in iron. In this case, the effect of directed bombardment of charged particles enhances the adsorption and diffusion of nitrogen. Since, during the process, there are mainly positive ions, excited atoms and electrons near the product, which is the cathode. These particles bombard the surface with an energy no less than the relaxation energy [14]. Since the electrolyteplasma nitriding is carried out under conditions of excessive excitation of the metal surface and subsurface layers. An important factor influencing the growth rate of the nitrided layer and its structure during this process is the exclusion of the predominant role of boundary diffusion. Plasma, accelerating the directional mass transfer of ions to the sample surface, creates conditions for uniform adsorption of nitrogen atoms over the entire metal surface, rather than selectively along the grain boundaries, as is observed with conventional nitriding. The results of experiments carried out in $[3,5]$, in particular, the results of metallographic analysis, mapping and energy dispersive analysis showed a uniform distribution of the thickness of the diffusion layer and a more uniform distribution of nitrogen over the surface of the nitrided layer. The observed phenomenon of uniform adsorption and uniform growth of the nitrided layer should be explained by the appearance in the grain volume of a special defect substructure (dislocation-disclination structure of grains in the near-surface zone), which were observed in experimental studies of the fine structure carried out in [3]. The resulting defectiveness, apparently, approaches the defectiveness of grain boundaries. The possibility of forming such a grain substructure during nitriding is provided by:

- increased energy state of the surface and subsurface layers exposed throughout the treatment to bombardment with ions and neutral atoms of low-temperature plasma;

- the counter flow of metal atoms and alloying elements to the metal - saturating medium interface, due to their high affinity for nitrogen;

- phase hardening and periodic recrystallization;

- the simultaneous diffusion of nitrogen atoms and the formation of defects in the crystal structure.

Thus, the use of an electric discharge in an electrolyte (low-temperature plasma) makes it possible to increase the heating rate and diffusion saturation of the surface of materials. The large depth of the modified layer is due to the intensification of the process, and the intensification of the saturation process is associated with the formation of a defect substructure when exposed to low-temperature plasma.

We have characterized the main processes of the formation of low-temperature plasma and its effect on a metal surface. Nevertheless, for a complete understanding of the processes occurring in the surface layers of a metal, during electrolyte-plasma nitriding in low-temperature plasma, as well as maximum use of the potential capabilities of the technological process, it is necessary to have its model, which would most accu- 
rately reflect the real essence of the phenomena. It is in this case that conditions are created for predicting the results of processing parts, as well as optimizing the technology.

According to its specific features, nitriding in an electrolyte plasma belongs to the technologies implemented using an electric discharge in a gas (vapor-gas shell) as an intensifier of the process. In the classical version, the part serves as a cathode. Several theoretical models of the interaction of a gaseous medium with a metal surface are known about this principle, which results in the creation of diffusion nitrogen-containing layers on the surface, modifying it in order to change its properties [15]. The theoretical provisions of the process are currently characterized by two main approaches.

The first of them was formed in solidarity by the scientists of the school of Yu.M. Lakhtin and the German school [16]. The essence of this model is demonstrated in Figure 2 [15, 17, 18], which has already become a classic in the theory of nitriding in a glow discharge.

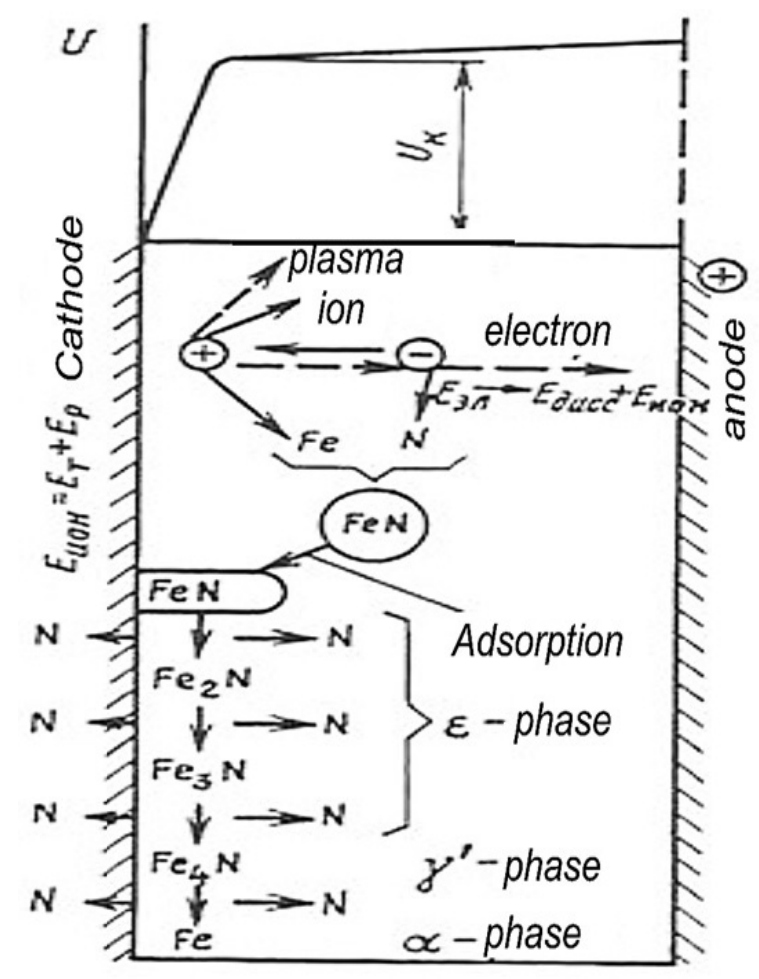

Figure 2. Scheme of plasma interaction with the cathode surface during nitriding in a glow discharge [15]

The initial premise of this model is the assumption that iron atoms in the glow discharge plasma combine with nitrogen, forming iron nitrides. They, in turn, under the influence of directed bombardment by charged particles, move in the direction of the cathode and are adsorbed by the surface. Then, already on the surface, the nitrides are transformed under the action of the surface bombardment by the incident flow, gradually transforming from the $\varepsilon$-phase into the $\gamma^{\prime}$-phase, the atomic nitrogen released in this case forms a solid solution of the $\alpha$-phase and diffusing into the depth of the surface. Thus, nitrogen enters the surface not only from the gas phase, but also as a result of the transformation of nitrides, and the driving force of the process is a high nitrogen concentration gradient.

The fundamental second model, the scientists of the school of Arzamasov BN, formulated a different principle of the process, which is demonstrated in Figure 3 [19]. According to this model, atomic nitrogen ions play the leading role in the nitriding process in a glow discharge. The intensity of the process is determined precisely by the number of atomic nitrogen ions. As a result of the bombardment of the surface, it can be sputtered, both in the form of neutral metal particles and its negative ions together with electrons. At the same time, a layer of adsorbed nitrogen particles forms on the surface as a result of the directed motion of particles in the field, recombination of ions directly on the surface, and also the release of some particles that have already penetrated into the surface at the gas-metal interface. Under the influence of the incident flow, the particles of the adsorbed layer can be sprayed or embedded into the surface, creating a solid solution. 


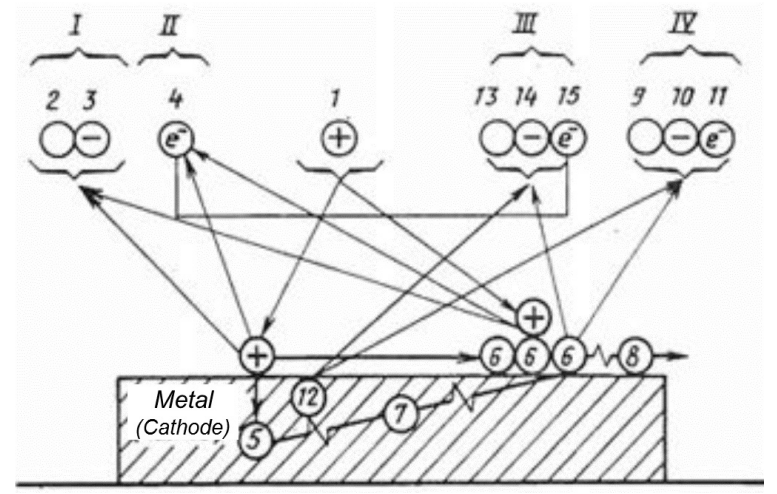

Figure 3. Scheme of the process of interaction of atomic particles with a metal in vacuum [15]

Thus, a fundamentally important difference between the above approaches is, first of all, the question of the primary formation of nitrides or a solid solution in the surface layers of the metal. According to the first model, nitrides are formed first, the transformation of which will lead to the formation of a solid solution. According to the second model, the excessive concentration of nitrogen in the solid solution, together with the energetic effect of the incident flow, promotes chemical transformations.

On the basis of these two models and the above-described processes occurring during nitriding, as well as the results obtained in $[3,5]$, it is possible to present a qualitative physical model of the interaction of lowtemperature plasma created in a carbamide-based electrolyte with the steel surface, due to which, the formation of wear-resistant modified surface layers occurs. Since there is no unified model in the literature for the interaction of low-temperature plasma with a metal surface during nitriding.

Thus, summarizing the available research results and taking into account the specific features of the process, a qualitative model of the interaction of low-temperature plasma with the steel surface during nitriding has been developed. The essence of the developed model is shown in Figure 4.

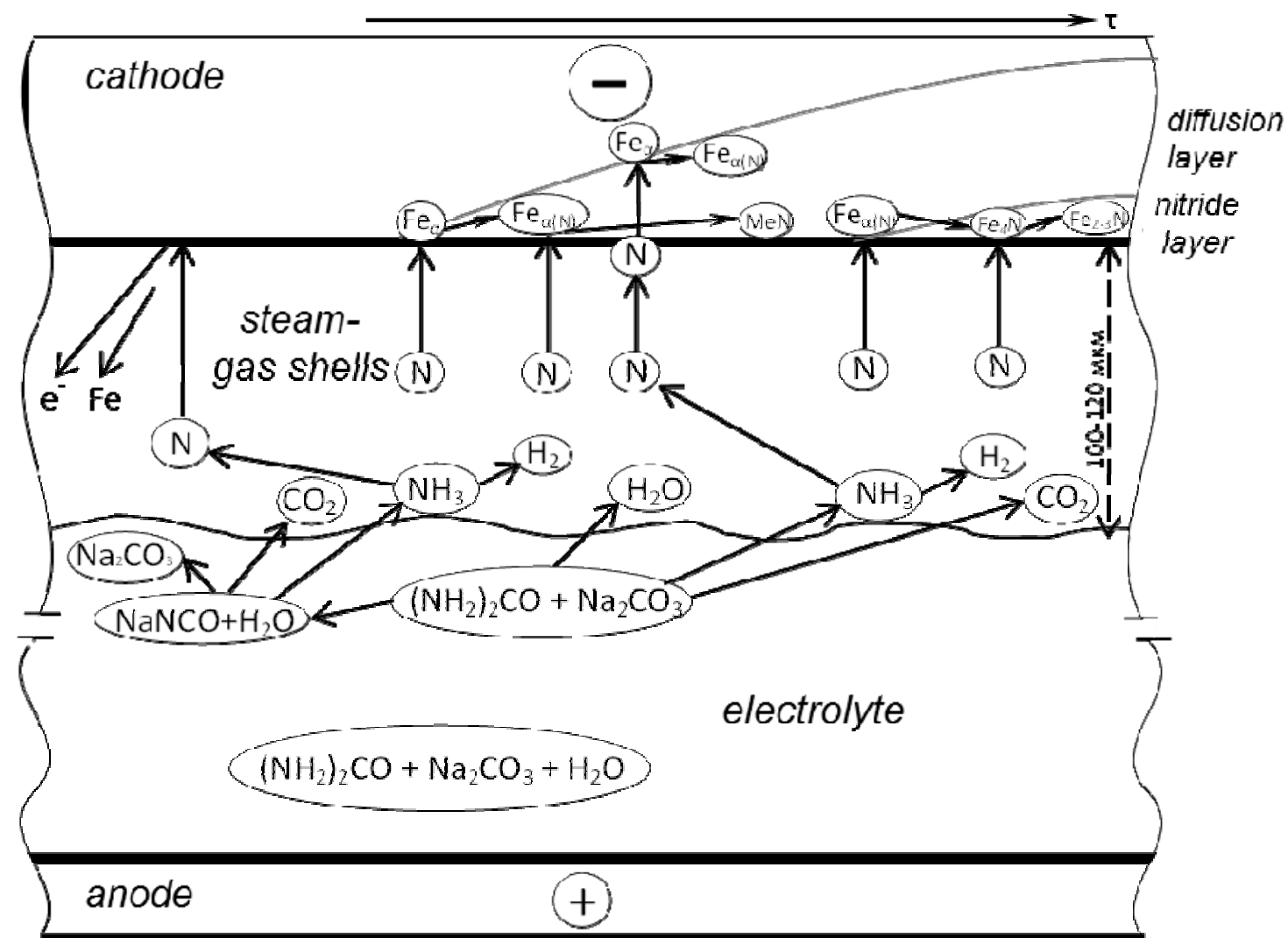

Figure 4. Model of the interaction of low-temperature plasma with the surface of steel during electrolyte-plasma nitriding 
In accordance with this model, in the first moments of the interaction of low-temperature plasma with the steel surface in the near-surface volume of steel, an accelerated formation of a $\mathrm{Fe}_{\alpha(\mathrm{N})}$ solid solution occurs due to the action of directed bombardment of charged particles, which enhances the adsorption and diffusion of nitrogen into the interior of the material, then as further saturation in places with an increased level of free energy (at lattice defects, at grain boundaries, etc.), dispersed particles of nitrides of alloying elements are formed. Further, when the limiting solubility of nitrogen in $\alpha$-iron is exceeded, transformations occur in the surface zone of the layer, leading to the formation of nitrides of the $\gamma^{\prime}$-phase $\left(\mathrm{Fe}_{4} \mathrm{~N}\right)$ and $\varepsilon$-phase $\left(\mathrm{Fe}_{2-3} \mathrm{~N}\right)$ in it. And during cooling, excess $\gamma^{\prime}$-nitride lamellar particles can form in the diffusion layer due to the formation of a highly supersaturated solid solution.

The developed model is formulated on the basis of experimental data and known regularities. So, in the first moments of the interaction of the vapor-gas shell (low-temperature plasma) with the surface of iron (steel), atomic nitrogen released in the vapor-gas shell during chemical reactions is adsorbed by the iron and diffuses deep into the material. In this case, the processes of adsorption and diffusion are enhanced by the action of directional bombardment of charged particles - positive ions and excited atoms. As a result of the bombardment of the surface, it can be sputtered in the form of neutral particles, negative metal ions and electrons. At the same time, a layer of adsorbed nitrogen particles forms on the surface as a result of the directed motion of particles in the field, recombination of ions directly on the surface, as well as the release of some particles that have already penetrated into the surface at the vapor-gas shell - metal interface. Under the influence of the incident flow, the particles of the adsorbed layer can be sprayed or embedded into the surface, creating a solid solution.

Penetrating into the crystal structure of steel, nitrogen can form not only solid solutions, but also chemical compounds - nitrides. The emergence of a new phase (nitrides) is accompanied by recrystallization of the system, which begins in places with an increased level of free energy (at lattice defects, at grain boundaries, etc.). There is an accumulation of diffusing elements, in particular nitrogen and the formation of a new crystal lattice - the nucleus of a new phase - is facilitated.

According to this model, solid solution of nitrogen in iron is the formed when iron is saturated with nitrogen, the primary result of the interaction of low-temperature plasma and the processed material. The formation of a chemical compound (nitrides) is a secondary process and occurs when the nitrogen content exceeds the maximum nitrogen concentration in a solid solution. So, $\mathrm{Fe}_{4} \mathrm{~N}$ nitride ( $\gamma^{\prime}$-phase) is formed when the limiting solubility of nitrogen in iron is exceeded and $\mathrm{Fe}_{2-3} \mathrm{~N}$ nitride ( $\varepsilon$-phase) is formed with a further increase in nitrogen concentration.

It should be noted that the process of diffusion saturation of the surface of materials and the formation of a diffusion layer occurs faster, since the rate of nitrogen diffusion in the $\gamma^{\prime}$-phase is 25 times less, and in the $\varepsilon$-phase it is 60 times less than in the $\alpha$-phase due to the gradual formation of a solid solution and a layer of compounds [20]. Also an important factor influencing the growth rate of the nitrided layer and its structure during this process is the exclusion of the predominant role of boundary diffusion. Since the electrolyteplasma nitriding is carried out under conditions of excessive excitation of the metal surface and subsurface layers. Plasma, accelerating the directional mass transfer of ions to the sample surface, creates conditions for uniform adsorption of nitrogen atoms over the entire metal surface, rather than selectively along the grain boundaries, as is observed with conventional nitriding.

As is known, the following phases can form in the $\mathrm{Fe}-\mathrm{N}$ system at nitriding temperatures: $\alpha$-nitrogen solution in iron, an intermediate $\gamma$-phase of variable composition with an FCC lattice (the formula $\mathrm{Fe}_{4} \mathrm{~N}$ is attributed to it), and an intermediate $\varepsilon$-phase with an HCP lattice and a wide region homogeneity (from 8.1 to $11.1 \% \mathrm{~N}$ at room temperature). According to the proposed model, nitrogen initially diffuses into the $\alpha$-phase with the formation of a solid solution of nitrogen in iron (nitrogenous martensite), with further saturation in places with an increased level of free energy (at lattice defects, at grain boundaries, etc.), dispersed particles are formed nitride alloying elements. Since elements such as $\mathrm{Cr}, \mathrm{Mo}, \mathrm{V}$ and others, dissolved in the matrix, increase the solubility of nitrogen in the $\alpha$-phase and form special nitrides $M N$ and $M_{2} N$. And after reaching the limit of nitrogen solubility in iron, the $\gamma$-phase $\left(\mathrm{Fe}_{4} \mathrm{~N}\right)$ and a high-nitrogen $\varepsilon$-phase $\left(\mathrm{Fe}_{2-3} \mathrm{~N}\right)$ are formed on the surface. However, in the selected and considered modes of nitriding, a nitride layer consisting of these phases is not detected on the surface. In this case, the formation of lamellar particles from the excess $\gamma$-phase $\left(\mathrm{Fe}_{4} \mathrm{~N}\right)$ is observed in the diffusion layer during cooling after nitriding. The formation of a continuous nitride layer consisting of the $\gamma$-phase and the $\varepsilon$-phase is observed only at long durations of the nitriding process in the electrolyte under consideration. 
Thus, the formation of finely dispersed nitrides of alloying elements after nitriding, as well as lamellar particles from the excess $\gamma$-phase $\left(\mathrm{Fe}_{4} \mathrm{~N}\right)$ in the near-surface layer of steel is quite natural. Since, previously carried out by the schools of Lakhtin [17,21], a systematic study of the kinetics and phase composition of the nitrided layer in alloyed steels showed differences in the specificity of the layer growth on alloyed ferrite and pure iron. The main difference is that nitrogen can interact with some alloying elements by forming special nitrides in addition to iron nitrides. At the same time, it was found that it is these nitrides of alloying elements and their degree of dispersion that ultimately determine the hardness of nitrided steel [22, 23].

Also, the formation of a $\gamma^{\prime}$-nitride particle in the diffusion layer during cooling can be explained as follows. During cooling to room temperature, a strongly supersaturated solid solution appears due to the poor solubility of nitrogen in the $\alpha$-phase at low temperatures. And this leads to the precipitation, preferably on dislocations, of $\alpha$-nitride particles of plate form with a certain orientation, which are further transformed into $\gamma^{\prime}$-nitrides $[15,24]$. The mechanism corresponds to the release of carbon and the formation of carbides during tempering of the hardened steel.

The experimental researches carried out in this work confirm the veracity of this model. So, the nitrided layer consists only of a diffusion solid solution (nitrogenous martensite), and an increase in the nitriding temperature to $500-550^{\circ} \mathrm{C}$ leads to the formation of nitrides in the solid solution $\gamma$-phase $\left(\mathrm{Fe}_{4} \mathrm{~N}\right)$ after electrolyte-plasma nitriding of high-speed steels at a temperature of $450{ }^{\circ} \mathrm{C}$ during 7 minutes. The nitrided layer consists of a diffusion layer $-\alpha+\gamma^{\prime}+\mathrm{MN}$ phase during the electrolyte-plasma nitriding of high-speed steels at a temperature of $550{ }^{\circ} \mathrm{C}$ during $7 \mathrm{~min}$. The formation of a nitrided layer consisting only of a diffusion layer without a nitride layer in the selected modes is associated with a low nitrogen concentration in a low-temperature plasma (vapor-gas envelope), as well as with a shorter nitriding duration. This is because much less nitrogen is usually required to form a diffusion layer on the surface of alloy steels than to form a compound layer (nitride layer) $[25,26]$. In addition, metallographic analysis of the modified layer, carried out in [3], showed that after electrolyte-plasma nitriding during $7 \mathrm{~min}$ in an electrolyte based on carbamide, a continuous nitride layer (iron nitride layer) was observed on the surface. Similar results were obtained in [27] during the electrolyte-plasma nitriding of structural steels in more active electrolytes based on ammonia.

The possibility of obtaining a modified layer consisting only of a diffusion layer $\left(\alpha+\gamma^{\prime}+\right.$ MN phases) on the surface of steels is the main advantage of electrolyte-plasma nitriding, in contrast to classical gas nitriding in ammonia, where a nitride layer is formed, consisting of two phases $-\gamma^{\prime}+\varepsilon$, which is a source of internal stresses at the interface and causes brittleness and flaking of the hardened layer during operation.

\section{Conclusions}

A qualitative model has been developed for the interaction of low-temperature plasma with a steel surface during electrolyte-plasma nitriding. In accordance with this model, in the first moments of the interaction of low-temperature plasma with the steel surface in the near-surface layer, an accelerated formation of the $\mathrm{Fe}_{\alpha(\mathrm{N})}$ solid solution occurs due to the action of directed bombardment of charged particles, which enhances the adsorption and diffusion of nitrogen into the interior of the material, then, as further saturation in In places with an increased level of free energy (at lattice defects, at grain boundaries, etc.), dispersed particles of nitride of alloying elements are formed. Subsequently, transformations occur in the surface zone of the layer, leading to the formation of nitrides of the $\gamma^{\prime}$-phase $\left(\mathrm{Fe}_{4} \mathrm{~N}\right)$ and $\varepsilon$-phase $\left(\mathrm{Fe}_{2-3} \mathrm{~N}\right)$ in it when the limiting solubility of nitrogen in iron is exceeded.

Thus, electrolyte-plasma nitriding opens up many new possibilities, in particular: varying the nitriding temperature over a wide range $\left(400-700^{\circ} \mathrm{C}\right)$, the targeted production of a nitrided layer consisting only of a diffusion layer without a layer of compounds, while obtaining a diffusion layer with particles $\gamma$-phase $\left(\mathrm{Fe}_{4} \mathrm{~N}\right)$ of plate form and with finely dispersed nitrides $\mathrm{MN}(\mathrm{CrN})$.

This paper was performed within the grant financing of scientific research for 2018-2020 of Committee of Science of the Ministry of Education and Science of the Republic of Kazakhstan. Grant BR05236748

\section{References}

1 Rakhadilov B.K. The cathodic electrolytic plasma hardening of the 20Cr2Ni4A chromium-nickel steel / B.K. Rakhadilov, V.V. Buranich, Z.A. Satbayeva, Zh.B. Sagdoldina, R.S. Kozhanova, A.D. Pogrebnjak // Journal of Materials Research and Technology. - 2020. - Vol. 9(4). - P. 6969-6976. 
2 Rakhadilov B.K. Influence of Electrolyte-Plasma Surface Hardening on the Structure And Properties of Steel 40HN / B.K. Rakhadilov, Z.A. Satbaeva, L.B. Bayatanova, M.K. Kilyshkanov, K.A. Kalibayev, A.K. Kochneva // Journal of Physics: Conference Series. - 2019. doi:10.1088/1742-6596/1393/1/012119. — URL: https://iopscience.iop.org/article/10.1088/1742$6596 / 1393 / 1 / 012119$

3 Skakov M. Influence of electrolyte plasma treatment on structure, phase composition and microhardness of steel P6M5 / M. Skakov, B. Rakhadilov, M. Sheffler // Key Engineering Materials. — 2013. - Vol. 531-532. — P. 627-631.

4 Zhurerova L.G. Effect of the PEN/C surface layer modification on the microstructure, mechanical and tribological properties of the 30CrMnSiA mild-carbon steel / L.G. Zhurerova, B.K. Rakhadilov, N.A. Popova, M.K. Kylyshkanov, V.V. Buraniche, A.D. Pogrebnjak // Journal of Materials Research and Technology. - 2020. - Vol. 9(1). - P. 291-300.

5 Rakhadilov B.K. Microstructure and Tribological Properties of Electrolyte Plasma Nitrided High Speed Steel /

B.K. Rakhadilov, M.K. Skakov, M. Scheffler // Materials testing. - 2015. — No. 4(57). — P. 360-365.

6 Белкин П.Н. Термическая и химико-термическая обработка сталей при нагреве в растворах электролитов / П.Н. Белкин, Е.А. Пасинковский // Металловедение и термическая обработка металлов. — 1989. — № 5. — С. $12-17$.

7 Суминов И.В. Плазменно-электролитическое модифицирование поверхности металлов и сплавов: [В 2 т.] / И.В. Суминов, П.Н. Белкин, А.В. Эпельфельд, В.Б. Людин, Б.Л. Крит, А.М. Борисов; под ред. И.В. Суминова. — М.: Техносфера, 2011. - T. 1. - 464 c.

8 Кидин И.Н. Электрохимико-термическая обработка металлов и сплавов / И.Н. Кидин, В.И. Андрюшечкин, В.А. Волков, А.С. Холин. - М.: Металлургия, 1978. - 320 с.

9 Самсонов Г.В. Некоторые особенности формирования покрытий в процессе реакционной диффузии / Г.В. Самсонов, Г.ЈI. Жуковский // Защитные покрытия на металлах. - 1974. — № 7. - С. 3-11.

10 Дураджи В.Н. Нагрев металлов в электролитной плазме / В.Н. Дураджи, А.С. Парсаданян. - Кишинев: Штиинца, 1988. - $216 \mathrm{c.}$

11 Словецкий Д.И. Механизмы неравновесных плазмохимических реакций / Д.И. Словецкий // Химия плазмы. - 1991. - T.3. - С. 94-100.

12 Белкин П.Н. Электрохимико-термическая обработка металлов и сплавов / П.Н. Белкин. — М.: Мир, 2005. — 336 с.

13 Федоренкова Л.И. Особенности диффузии при обработке металлов в электролитной плазме / Л.И. Федоренкова // Вестн. Днепропетр. ун-та. Сер. Физика. Радиоэлектроника. — 2007. — № 12/1(14). — С. 104-106.

14 Оулет Р. Технологическое применение низкотемпературной плазмы / Р. Оулет, М. Барбье. - М.: Энергоатомиздат, 1983. - $144 \mathrm{c}$.

15 Пастух И.М. Теория и практика безводородного азотирования в тлеющем разряде / И.М. Пастух. — Харьков: ННЦ ХФТИ, 2006. - $364 \mathrm{c.}$

16 Edenhofer B. Physikalishe und metallkundliche Vorgange beim Nitriren in Plasma einer Glimmentladung / B. Edenhofer // Harterei-Technishe Mitteilungen. — 1974. - Vol. 29(2). — P. 105-112.

17 Лахтин Ю.М. Теория и технология азотирования / Ю.М. Лахтин, Я.Д. Коган, Г.Й. Шпис, З. Бемер. - М.: Металлургия, 1991. - $320 \mathrm{c.}$

18 Панайоти Т.А. Азотирование высокопрочных сталей и сплавов в тлеющем разряде / Т.А. Панайоти. - М.: Машиностроение, 1989. - 40 с.

19 Арзамасов Б.Н. Ионная химико-термическая обработка сплавов / А.Г. Братухин, Ю.С. Елисеев, Т.А. Панайоти. М.: Изд-во МВТУ им. Н.Э. Баумана, 1999. - 400 с.

20 Сыропятов В.Я. Современная концепция азотного потенциала / В.Я. Сыропятов, В.М. Зинченко, Ю.А. Перекатов // Металловедение и термическая обработка металлов. - 2004. - № 1. - С. 7-12.

21 Лахтин Ю.М. Химико-термическая обработка металлов / Ю.М. Лахтин, Б.Н. Арзамасов. — М.: Металлургия, 1985. $-256 \mathrm{c}$.

22 Guo-meng Li. Study of M50NiL steel under carburizing and nitriding duplex treatment / Li Guo-meng, Liang Yi-long, Yin Cun-hong, Sun Hao, Zhu Zhen-long // Surface and Coatings Technology. — 2019. - Vol. 375. — P. 132-142.

23 Xiangfeng Zhang. Pan Erosion-corrosion resistance properties of 316L austenitic stainless steels after low-temperature liquid nitriding / Xiangfeng Zhang, JunWang, Hongyuan Fan, Dong Pan // Applied Surface Science. — 2018. — Vol. 440. - P. 755-762.

24 Герасимов С.А. Структура и износостойкость азотированных сталей и сплавов / С.А. Герасимов, Л.И. Куксенова, В.Г. Лаптева. - М.: Изд-во МГТУ им. Н.Э. Баумана, 2012. - 518 с.

25 Петрова Л.Г. Комбинированная технология диффузионного насыщения металлами углеродистых сталей, совмещённая с гидроплазменным азотированием / В.А. Александров, П.Е. Демин // Вестн. ХНАДУ. - 2011. — № 54. - С. 52-58.

26 Belkin P. Anodic Plasma Electrolytic Saturation of Steels by Carbon and Nitrogen / A. Naumov, S. Shadrin, I. Dyakov, A. Zhirov, S. Kusmanov, T. Mukhacheva // Advanced Materials Research. - 2013. — Vol. 704. — P. 37-42.

27 Белкин П.Н. Химико-термическое упрочнение стальных деталей при анодном процессе / П.Н. Белкин, Е.А. Пасинковский, А.К. Товарков // Надежность и долговечность машин и сооружений. - 1990. — № 18. — С. 80-86. 
Р.С. Кожанова, Б.К. Рахадилов, В. Виелеба

\title{
Карбамид негізіндегі электролитте электролитті-плазмалық азоттау кезінде төментемпературалы плазманың болат бетімен өзара әрекеттесу моделі
}

\begin{abstract}
Мақалада төментемпературалы плазманың пайда болу ерекшеліктері және оның металл бетімен өзара әрекеттесуі зерттелді. Зерттеу нәтижелерін қорытындылай келе және электролит-плазмалық процестің өзіндік ерекшеліктерін ескере отырып, электролит-плазмалық азоттау кезінде төментемпературалы плазманың болат бетімен өзара әрекеттесуінің сапалы моделі жасалды. Осы модельге сәйкес, төментемпературалы плазманың болаттың бетімен әрекеттесуінің алғашқы сәттерінде беткі қабаттағы қатты ерітіндінің тез түзілуі жүреді, $\mathrm{Fe}_{\alpha(\mathrm{N})}$ зарядталған бөлшектерді бағытталған бомбалаудың әсерінен, материалдың тереңдігіне азоттың адсорбциясы мен диффузиясын күшейтеді, содан кейін еркін энергия деңгейі жоғары жерлерде одан әрі қанығады (тордың ақауларында, астық шекараларында және т.б.). Легірлеуші элементтердің нитридінің дисперсті бөлшектері пайда болады. Одан әрі қабаттың беткі аймағында азоттың шекті ерігіштігі асып кетсе, онда $\gamma^{\prime}$-фаза $\left(\mathrm{Fe}_{4} \mathrm{~N}\right)$ және $\varepsilon$-фаза $\left(\mathrm{Fe}_{2-3} \mathrm{~N}\right)$ нитридтерінің пайда болуына әкелетін өзгерістер болады. Осылайша, электролитті-плазмалық азоттандыру көптеген жаңа мүмкіндіктерді ашады, атап айтқанда: азоттандыру температурасының кең ауқымдағы өзгеруі $\left(400-700{ }^{\circ} \mathrm{C}\right)$, азотталған қабатты мақсатты түрде алу, тек диффузиялық қабаттан тұратын қосылыстар қабаты жоқ, ал диффузиялық қабатты $\alpha^{\prime}$-фазалы бөлшектермен $\left(\mathrm{Fe}_{4} \mathrm{~N}\right)$ пластиналық пішінді және $\mathrm{MN}(\mathrm{CrN})$ ұсақ дисперсті нитридтерімен алу. Электролитте (төментемпературалы плазма) электр разрядын қолдану материалдар бетінің қыздыру және диффузиялық қанықтыру жылдамдығын арттыруға мүмкіндік береді. Бұл жұмыстың практикалық маңызы зор, өйткені электролитті плазмалық азоттаудың зерттелген әдісі жоғары физика-механикалық қасиеттері бар болаттарға модификацияланған беткі қабатты алуға мүмкіндік береді.
\end{abstract}

Кілт сөздер: плазма, электролит-плазмалық өңдеу, азоттандыру, қанықтыру, электролит, болат, модель, модификацияланған қабат, фаза.

\author{
Р.С. Кожанова, Б.К. Рахадилов, В. Виелеба
}

\section{Модель взаимодействия низкотемпературной плазмы с поверхностью стали при электролитно-плазменном азотировании в электролите на основе карбамида}

\begin{abstract}
В статье изучены особенности образования низкотемпературной плазмы и ее взаимодействия с металлической поверхностью. Обобщая имеющиеся результаты исследований и учитывая специфические особенности электролитно-плазменного процесса, разработана качественная модель взаимодействия низкотемпературной плазмы с поверхностью стали при электролитно-плазменном азотировании. В соответствии с этой моделью, в первые моменты взаимодействия низкотемпературной плазмы с поверхностью стали в приповерхностном слое происходит ускоренное образование твердого раствора $\mathrm{Fe}_{\alpha(\mathrm{N})}$ за счет воздействия направленной бомбардировки заряженных частиц, усиливающего адсорбцию и диффузию азота в глубь материала, затем, по мере дальнейшего насыщения, в местах с повышенным уровнем свободной энергии (на дефектах решетки, на границах зерен и т.п.) образуются дисперсные частицы нитрида легирующих элементов. В дальнейшем при превышении предельной растворимости азота в железе в поверхностной зоне слоя происходят превращения, приводящие к образованию в ней нитридов $\gamma^{\prime}$-фазы $\left(\mathrm{Fe}_{4} \mathrm{~N}\right)$ и $\varepsilon$-фазы $\left(\mathrm{Fe}_{2-3} \mathrm{~N}\right)$. Таким образом, электролитно-плазменное азотирование открывает множество новых возможностей, в частности, варьирование температурой азотирования в широких пределах $\left(400-700{ }^{\circ} \mathrm{C}\right)$; целенаправленное получение азотированного слоя, состоящего только из диффузионного слоя без слоя соединений, при этом получение диффузионного слоя с частицами $\alpha^{\prime}$-фазы $\left(\mathrm{Fe}_{4} \mathrm{~N}\right)$ пластинчатой формы и с мелкодисперсными нитридами $\mathrm{MN}(\mathrm{CrN})$. Применение электрического разряда в электролите (низкотемпературной плазмы) позволяет увеличить скорость нагрева и диффузионного насыщения поверхности материалов. Данная работа имеет важное практическое значение, так как изучаемый способ электролитно-плазменного азотирования позволяет получить модифицированный поверхностный слой на сталях с высокими физикомеханическими свойствами.
\end{abstract}

Ключевые слова: плазма, электролитно-плазменная обработка, азотирование, насыщение, электролит, сталь, модель, модифицированный слой, фаза. 


\section{References}

1 Rakhadilov, B.K., Buranich, V.V., Satbayeva, Z.A., Sagdoldina, Zh.B., Kozhanova, R.S., \& Pogrebnjak, A.D. (2020). The cathodic electrolytic plasma hardening of the 20Cr2Ni4A chromium-nickel steel. Journal of Materials Research and Technology, 9(4), 6969-6976.

2 Rakhadilov, B.K., Satbaeva, Z.A., Bayatanova, L.B., Kilyshkanov, M.K., Kalibayev, K.A., \& Kochneva, A.K. (2019). Influence of Electrolyte-Plasma Surface Hardening on the Structure And Properties of Steel 40HN. Journal of Physics: Conference Series, doi:10.1088/1742-6596/1393/1/012119. Retrieved from: https://iopscience.iop.org/article/10.1088/1742-6596/1393/1/012119

3 Skakov, M., Rakhadilov, B. \& Sheffler, M. (2013). Influence of electrolyte plasma treatment on structure, phase composition and microhardness of steel P6M5. Key Engineering Materials, 531-532, 627-631.

4 Zhurerova, L.G., Rakhadilov, B.K., Popova, N.A., Kylyshkanov, M.K., Buraniche, V.V., \& Pogrebnjak, A.D. (2020). Effect of the PEN/C surface layer modification on the microstructure, mechanical and tribological properties of the $30 \mathrm{CrMnSiA}$ mildcarbon steel. Journal of Materials Research and Technology, 9(1), 291-300.

5 Rakhadilov, B.K., Skakov, M.K., \& Scheffler, M. (2015). Microstructure and Tribological Properties of Electrolyte Plasma Nitrided High Speed Steel. Materials testing, 4(57), 360-365.

6 Belkin, P.N. \& Pasinkovskiy, E.A. (1989). Termicheskaia i khimiko-termicheskaia obrabotka stalei pri nahreve v rastvorakh elektrolitov [Thermal and chemical-thermal treatment of steels when heated in electrolyte solutions]. Metallovedenie $i$ termicheskaia obrabotka metallov - Metal science and heat treatment, 5, 12-17 [in Russian].

7 Suminov, I.V., Belkin, P.N., Epelfeld, A.V., Lyudin, V.B., Krit, B.L., Borisov, A.M. (Ed. by I.V. Suminova), (2011). Plazmenno-elektroliticheskoe modifitsirovanie poverkhnosti metallov i splavov [Plasma-electrolytic modification of the surface of metals and alloys]. Moscow: Tekhnosfera [in Russian].

8 Kidin, I.N., Andryushechkin, V.I., Volkov, V.A., \& Kholin, A.S. (1978). Elektrokhimiko-termicheskaia obrabotka metallov $i$ splavov [Electrochemical and heat treatment of metals and alloys]. Moscow: Metallurhiia [in Russian].

9 Samsonov, G.V., \& Zhunkovskiy, G.L. (1974). Nekotorye osobennosti formirovaniia pokrytii v protsesse reaktsionnoi diffuzii [Some features of coating formation in the process of reaction diffusion]. Zashchitnye pokrytiia na metallakh - Protective coatings on metals, 7, 3-11 [in Russian].

10 Duradzhi, V.N., \& Parsadanyan, A.S. (1988). Nahrev metallov v elektrolitnoi plazme [Heating of metals in an electrolyte plasma]. Kishinev: Shtiintsa [in Russian].

11 Slovetskiy, D.I. (1991). Mekhanizmy neravnovesnykh plazmokhimicheskikh reaktsii [Mechanisms of non-equilibrium plasma-chemical reactions]. Khimiia plazmy - Plasma chemistry, 3, 94-100 [in Russian].

12 Belkin, P.N. (2005). Elektrokhimiko-termicheskaia obrabotka metallov i splavov [Electrochemical and heat treatment of metals and alloys]. Moscow: Mir [in Russian].

13 Fedorenkova, L.I. (2007). Osobennosti diffuzii pri obrabotke metallov v elektrolitnoi plazme [Features of diffusion in the treatment of metals in an electrolyte plasma]. Vestnik Dnepropetrovskoho universiteta. Seriia Fizika. Radioelektronika - Bulletin of the Dnepropetrovsk University. Series Physics. Radionics, 12/1(14), 104-106 [in Russian].

14 Oulet, R., \& Barbye, M. (1983). Tekhnolohicheskoe primenenie nizkotemperaturnoi plazmy [Technological application of low-temperature plasma]. Moscow: Enerhoatomizdat [in Russian].

15 Pastukh, I.M. (2006). Teoriia i praktika bezvodorodnoho azotirovaniia v tleiushchem razriade [Theory and practice of hydrogen-nitriding in a glow discharge]. Kharkov: NNTs KhFTI [in Russian].

16 Edenhofer, B. (1974). Physikalishe und metallkundliche Vorgange beim Nitriren in Plasma einer Glimmentladung. HartereiTechnishe Mitteilungen, 29(2), 105-112.

17 Lakhtin, Yu.M., Kogan, Ya.D., Shpis, G.Y., \& Bemer, Z. (1991). Teoriia i tekhnolohiia azotirovaniia [Theory and technology of nitriding]. Moscow: Metallurhiia [in Russian].

18 Panayoti, T.A. (1989). Azotirovanie vysokoprochnykh stalei i splavov v tleiushchem razriade [Nitriding of high-strength steels and alloys in a glow discharge]. Moscow: Mashinostroenie [in Russian].

19 Arzamasov, B.N., Eliseyev, Yu.S., \& Panayoti, T.A. (1999). Ionnaia khimiko-termicheskaia obrabotka splavov [Ionic chemical-heat treatment of alloys]. Moscow: N.E. Bauman MHTU Publ. [in Russian].

20 Syropyatov, V. Ya., Zinchenko, V.M., \& Perekatov, Yu.A. (2004). Sovremennaia kontseptsiia azotnoho potentsiala [The modern concept of the nitrogen pote]. Metallovedenie i termicheskaia obrabotka metallov - Metal science and heat treatment, 1, 712 [in Russian].

21 Lakhtin, Yu.M., \& Arzamasov, B.N. (1985). Khimiko-termicheskaia obrabotka metallov [Chemical and heat treatment of metals]. Moscow: Metallurhiia [in Russian].

22 Guo-meng Li, Yi-long Liang, Cun-hong Yin, Hao Sun, \& Zhen-long Zhu (2019). Study of M50NiL steel under carburizing and nitriding duplex treatment. Surface and Coatings Technology, 375, 132-142.

23 Xiangfeng Zhang, JunWang, Hongyuan Fan, Dong Pan (2018). Erosion-corrosion resistance properties of 316L austenitic stainless steels after low-temperature liquid nitriding. Applied Surface Science, 440, 755-762.

24 Gerasimov, S.A., Kuksenova, L.I., \& Lapteva, V.G. (2012). Struktura i iznosostoikost azotirovannykh stalei i splavov [Structure and wear resistance of nitrided steels and alloys]. Moscow: N.E. Bauman MSTU Publ. [in Russian].

25 Petrova, L.G., Aleksandrov, V.A., \& Demin, P.Ye. (2011). Kombinirovannaia tekhnolohiia diffuzionnoho nasyshcheniia metallami uhlerodistykh stalei, sovmeshchonnaia s hidroplazmennym azotirovaniem [Combined technology of diffusion saturation of carbon steel metals combined with hydroplasma nitriding]. Vestnik Kharkovskoho natsionalnoho avtomobilno-dorozhnoho universiteta - Bulletin of the Kharkiv National Automobile and Highway University, 54, 52-58 [in Russian].

26 Belkin, P., Naumov, A., Shadrin, S., Dyakov, I., Zhirov, A., Kusmanov, S., \& Mukhacheva, T. (2013). Anodic Plasma Electrolytic Saturation of Steels by Carbon and Nitrogen. Advanced Materials Research, 704, 37-42.

27 Belkin, P.N., Pasinkovskiy, E.A., \& Tovarkov, A.K. (1990). Khimiko-termicheskoe uprochnenie stalnykh detalei pri anodnom protsesse [Chemical-thermal hardening of steel parts during the anodic process]. Nadezhnost $i$ dolhovechnost mashin $i$ sooruzhenii - Reliability and durability of machines and structures, 18, 80-86 [in Russian]. 